International Review of Research in Open and Distributed Learning Volume 18, Number 5

August - 2017

\title{
The Use of Social Media in E-Learning: A Metasynthesis
}

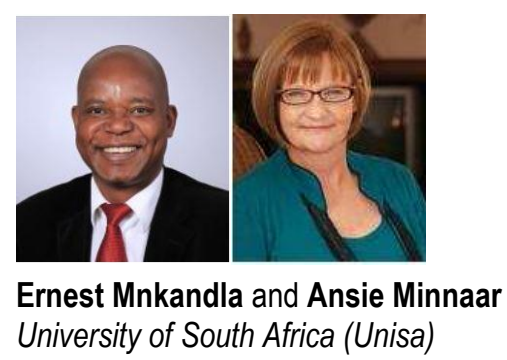

"Technology never teaches pupils, it simply creates conditions under which they can learn" (Adapted from Albert Einstein 1879 - 1955)

\begin{abstract}
The adoption of social media in e-learning signals the end of distance education as we know it in higher education. However, it appears to have very little impact on the way in which open and distance learning (ODL) institutions are functioning. Earlier research suggests that a significant part of the explanation for the slow uptake of social media in e-learning lies outside of conventional factors attributed to distance learning reforms.

This research used the conceptual framework for online collaborative learning (OCL) in higher education. Social media such as blogs, wikis, Skype or Google Hangout, Facebook; and even mobile apps, such as WhatsApp; could facilitate deep learning and the creation of knowledge in e-learning at higher educational institutions.

This metasynthesis is an interpretative integration of peer-reviewed qualitative research findings on social media in e-learning. It includes a synthesis of data, research methods, and theories used to investigate social media in e-learning. Seven themes emerged from the data which have been recrafted into a framework for social media in e-learning as the final product. The proposed framework could be useful to instructional designers and academics who are interested in using modern learning theories and want to adopt social media in e-learning in higher education as a deep learning strategy.
\end{abstract}

Keywords: Open distance learning, social media, e-learning, qualitative research, metasynthesis, online collaborative learning 


\section{The Use of Social Media in E-Learning: A Metasynthesis}

This research represents a conceptual framework designed to explain the adoption of social media into elearning by using online collaborative learning (OCL) in higher education. Social media in e-learning signals the end of distance education in higher education. However, it appears to have very little impact on how ODL institutions are functioning. Earlier research suggests that a significant part of the explanation for the slow uptake of social media in e-learning is because of the many changes in social media which leave academics lagging behind permanently, leaving them-and sometimes also the students-unable to grasp the affordances of social media landscape in education (Carpenter \& Krutka, 2015). Conditions such as the lack of capacity in higher educational institutions, the large number of underqualified educators with poor technological skills, and political resistance to a shift towards a more technologically enhanced learning paradigm might be cited as reasons.

Close to two decades of experiences in using e-learning tools, an abundance of social media options available, and the analysis of literature such as Mehlenbacher et al. (2005), Petersen (2007), Park (2011), and Hadjerrouit (2010) led to a realization of the importance of the usability of social media in open and distance and e-learning (ODeL). This research investigates the use of social media in e-learning. The continued use of social media such as wikis, blogs, discussions, Facebook, and Twitter as tools in education, to name but a few, have led to a proliferation of technologies that have not necessarily been designed for teaching and learning (Harasim, 2012). If these tools, commonly used in our day-to-day lives, are not easy to use in education; or if they lack important functionalities to enable learning, there would be no benefit in using them.

It is, therefore, desirable to identify the usability, limitations, and strategies for using social media in elearning to provide a framework for the effective use of applications and technological tools in higher education. E-learning and social media are widely described in higher education, but the tools and the specific uses in higher education for learning are not clear from the literature. Social media must be used for specific purposes in e-learning to effectively facilitate social learning, collaboration, and interaction among students and between students and lecturers to enhance deep learning in a safe environment. Social media is used most often as something nice to have in e-learning without acknowledging or considering the specific purpose and educational theory behind its usage (Bates, 2015).

In addition, there is a need to explore the most suitable social media for specific learning purposes according

to constructivism and the online collaborative learning theory as described by Harasim (2012). The proliferation of studies dealing with social media in e-learning lack direction for the implementation of the findings; therefore, it was necessary to synthesize the knowledge generated in this area to draw conclusions from the use of social media in e-learning in higher education.

\section{Background and Theoretical Framework of the Study}

Online collaborative learning theory focuses on educational applications that facilitate idea generation, idea organization, and intellectual convergence through the internet (Harasim, 2012). The OCL theory was 
proposed by Harasim and is composed of three intellectual phases: namely, idea generating (IG); idea organizing (IO); and intellectual convergence (IC). Idea generating is the first phase during which the collaborating group is characterized by differing ideas and activities resulting from brainstorming, verbalizing, and generating information, which lead to the sharing of information and subsequently to positions on a problem of interest (Harasim, 2012).

Secondly, idea organizing mainly focuses on the process of conceptual change, intellectual progress, and a shift towards convergence of ideas to cluster them according to their strengths and relationships or the lack thereof (Harasim, 2012). Intellectual convergence is the third and final phase of the OCL theory and is, in simplest terms, a knowledge construction (Harasim, 2012). The OCL theory manifests into scientific knowledge or hypotheses and social application resulting in knowledge building. Figure 1 presents a graphic view of the OCL theory.

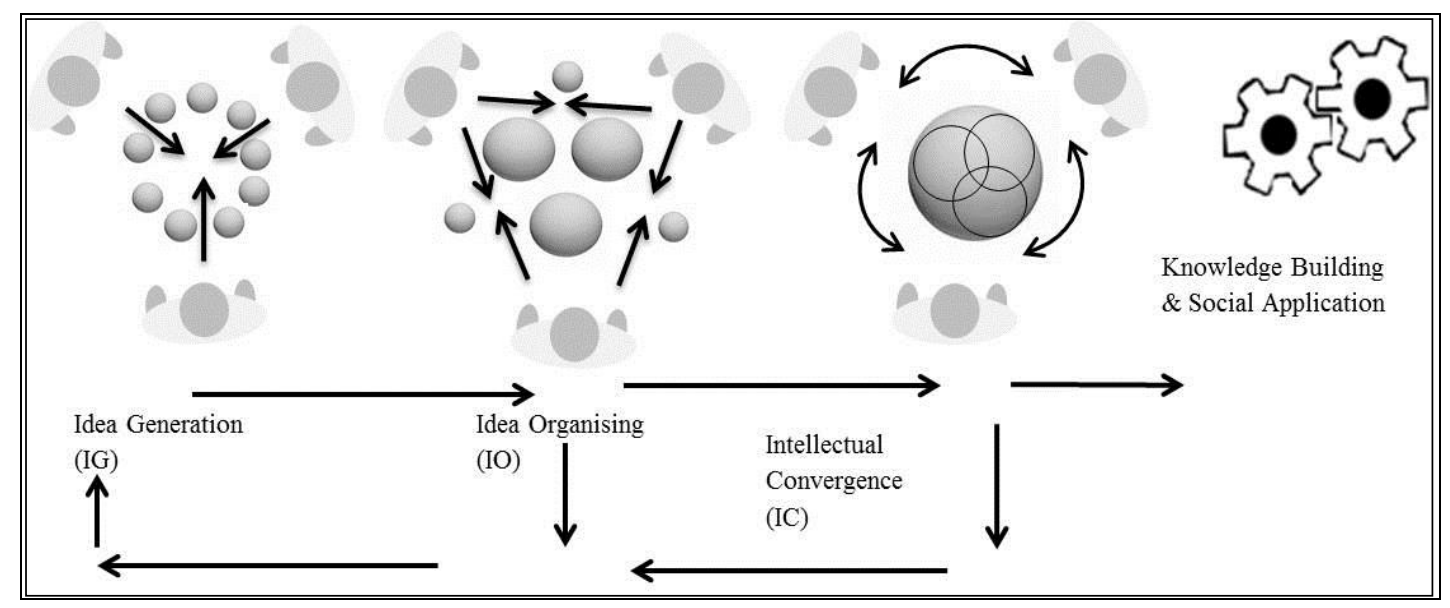

Figure 1. Three intellectual phases of online collaborative learning (adapted from Harasim (2012, 94).

In order to facilitate idea generation, idea organization, intellectual convergence and knowledge building in e-learning, social media, and technologies are needed to facilitate collaborative interactivity in e-learning. The purpose of this research was, therefore, to investigate the usability of social media as educational tools in e-learning in order to identify key aspects and strategies to develop a framework which could inform higher education facilitators on the usability of social media in e-learning.

There is a growing body of knowledge on using social media in e-learning. The results of research in the use of social media in e-learning in higher education are diverse and pose a problem to academics that need to select social media; therefore, a theoretical framework would be suitable to use in e-learning for deep learning and maximum student support. Furthermore, academics are overwhelmed by the wide range of social media for teaching and learning. A theoretical framework could guide decisions in selecting social media available for maximum impact on e-learning in ODL and other higher educational institutions. This metasynthesis synthesizes primary qualitative peer-reviewed research studies on the use of social media in e-learning in higher education from 2000 to 2015 as a metasynthesis focuses on synthesizing qualitative research. 


\section{Research Method}

Qualitative, interpretive metasynthesis of data from primary qualitative research studies worldwide was used for the study, using various qualitative methods such as phenomenology, case studies, and ethnography; grounded theory approaches were also included. According to Figure 2, the components of a metasynthesis research study involve three components; namely, meta-data analysis, meta-theory analysis, and a meta-method analysis. A metasynthesis is derived from the results of the analytic components of the meta-method, meta-data analysis, and the meta-theory as displayed in Figure 2.

The research process in a metasynthesis is composed of four distinct components; namely the analytic components of meta-data analysis, meta-method, and the meta-theory and the synthesis component in the form of a metasynthesis as described below in this paper. In this paper, we referred to the metasynthesis as investigations of results and processes of previous research (primary research). In effect, a metasynthesis is research of research. It entails analysis, the scrutiny of the theory, research methods and data analysis of research on social media, e-learning, and culminates into a synthesis while it generates new knowledge.

Our review has a limitation related to the construction of the sample of articles. We encountered a problem in searching for primary qualitative research with poorly written abstracts of all research aspects, but mostly, with methodological issues. This created "false negatives" in our initial sample of qualitative articles in the sense that a large number of publications were not excluded when the abstracts were read for the first time, as displayed in Figure 3.

Firstly, the meta-method analysis entails a thoughtful examination of how the research methodological approach is used to gather and interpret the data. Secondly, the meta-data analysis involves reinterpretations of the actual findings from the primary qualitative studies. Thirdly, the meta-theory analysis consists of an examination of the theories that lead the topics, frameworks, and research questions of primary researchers (Sandelowski, Trimble, Woodard, \& Barroso, 2006; Thorne et al., 2002). 


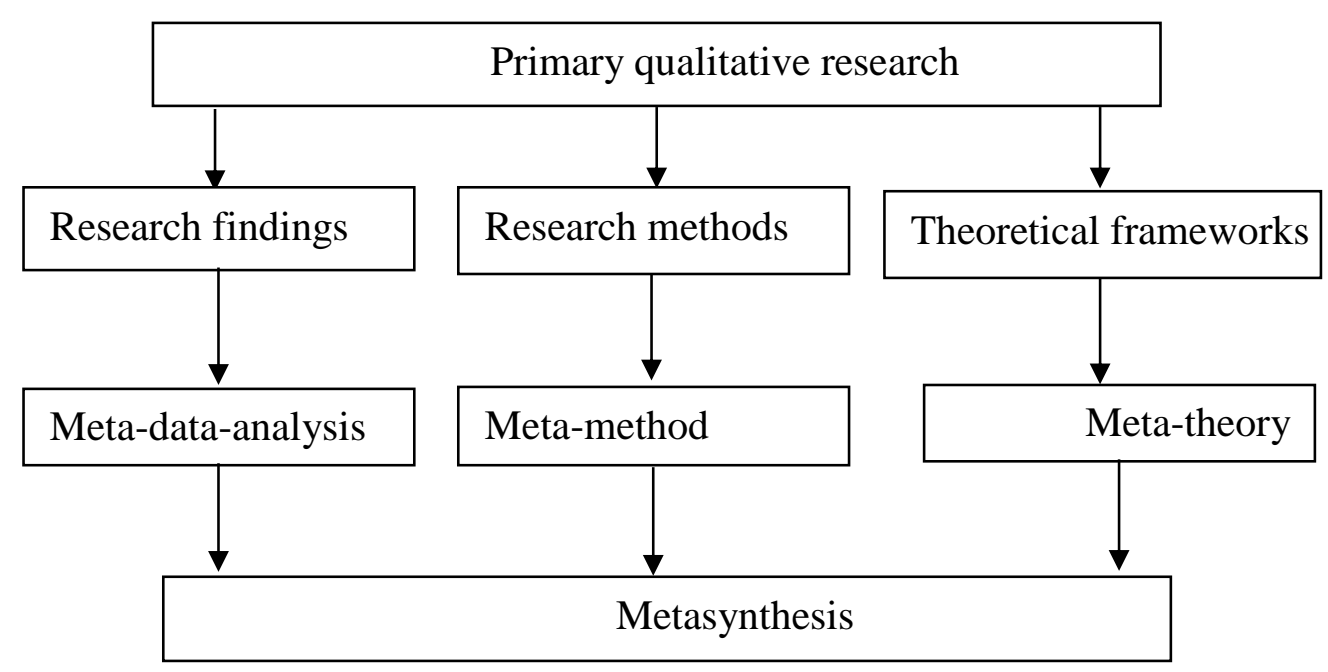

Figure 2. Components of a meta-synthesis adopted from Thorne et al., (2002) Sandelowski, Trimble, Woodard, \& Barroso (2006).

\section{The Literature Search or Retrieval and Assessment of Primary Qualitative Search}

The search terms included open distance learning, social media, e-learning, qualitative research, and social networks. These terms were submitted to the search librarian of the University of South Africa. One of the researchers also searched online using the same terms. The search was done on South African and international academic databases, which included SAe-Publications, EBSCOhost: Academic Search Premier, Education Source, Business Source Premier, ERIC (Educational Resources Information Center), Educator's Reference Desk, PsycEXTRA, ProQuest: ProQuest Education Journals, International Bibliography of the Social Sciences (IBSS), Educational PSYCHOLOGY, Academic OneFile, Emerald, ISI Web of Knowledge, Google Scholar, AIS eLibrary, and JStor. Individual journal searches were consulted.

From the literature searches, we identified 195 articles to be screened for the study from our literature searches. One hundred and sixty-five articles were excluded on the grounds of research methodologies as not qualitative research. At first, the majority of data sources from the 195 articles seemed to be qualitative research, but, on closer scrutiny, it was determined that they were mixed method research projects. Figure 3 is a summary of the screening and selection process.

The abstracts of 30 articles were read to determine if the research they reported was about social media in e-learning. This review process rejected 19 articles because they did not have a qualitative research focus on e-learning and social media in higher education. The 11 articles screened by using the criteria in Table 1 did not comply with the research rigour guideline which we as researchers set at $80 \%$ for inclusion into the study. The last stage of the selection of articles involved a full scan of six articles that met the criteria for qualitative research methodological rigour as set out in Table 1 and Figure 3. Figure 3 displays the process of data source selection on the grounds of inclusion and exclusion criteria. Secondly, we used Table 1 to 
further screen the qualitative article to ensure that the most applicable qualitative research on e-learning and the use of social media was included in the metasynthesis.

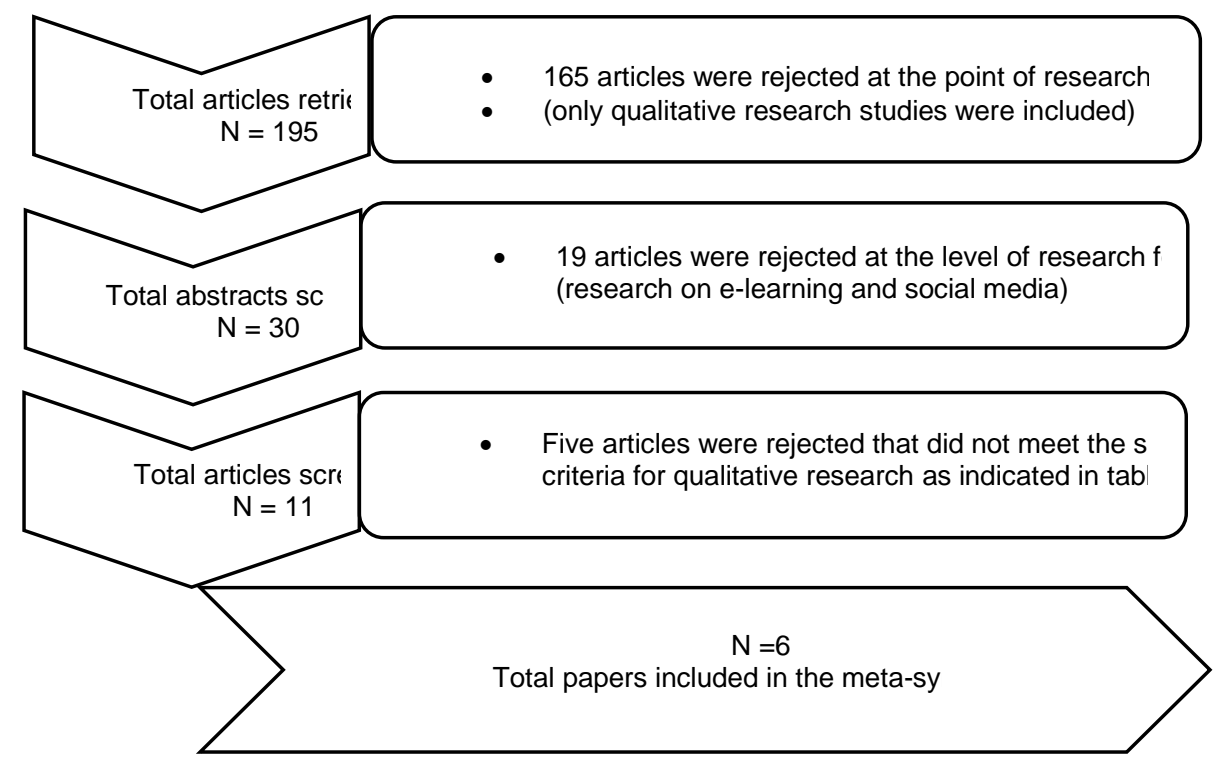

Figure 3. Summary of research study screening and selection process.

\section{Inclusion and Exclusion Criteria}

Inclusion criteria were set to obtain qualitative articles on the usability of social media in e-learning in higher education institutions from 2000 to 2015. We included articles with a qualitative research strategy; qualitative research sampling in higher education; e-learning and social media in teaching and learning; and articles in which data were collected from learners, academics, or the online activities of the groups. Lastly, the research articles were screened for research rigour as displayed in Table 1 and an article must have received $80 \%$ or higher to be included into the study.

The body of qualitative work on online learning has grown over the last two decades; thus, so has the emphasis on a metasynthesis. Articles that received less than $79 \%$ for research rigour were excluded from the study. Articles that did not deal with higher education, e-learning, and literature reviews were excluded since they were not the focus of this research. Most of the weaknesses in the published articles that were excluded after using the screening criteria in Table 1 were issues around the use of quantitative and qualitative methodologies (mixed method research methodologies) as a metasynthesis is focused on qualitative peer reviewed articles only. Weaknesses in the qualitative articles such as sampling, focus, and mixed methods research contributed to the small sample in this metasynthesis. The rigorous process of inclusion and exclusion and screening processes ensured that the best peer-reviewed qualitative research articles on e-learning and social media in higher education were selected for the metasynthesis as depicted in Table 2. 
Table 1

Screening Criteria (Adapted from Paterson et al., 2001)

\begin{tabular}{|l|l|l|l|l|}
\hline No. & Screening criteria for inclusion and exclusion & $\mathbf{2}$ & $\mathbf{0}$ & $\mathbf{1}$ \\
$\mathbf{N o}$ & $\mathbf{N} / \mathbf{A}$ \\
\hline $\mathbf{1}$ & Research question stated clearly and adhered to & & & \\
\hline $\mathbf{2}$ & Design clearly planned & & & \\
\hline 4 & Aims of the study clearly described & & & \\
\hline 5 & Dampling clearly described & & & \\
\hline 6 & How were data collected? & & & \\
\hline 7 & How were data recorded and ethical aspects described? & & & \\
\hline 8 & Data analysis described with transferability & & & \\
\hline 9 & How were themes and categories identified? & & & \\
\hline 10 & Credibility (member checks, validation of data) & & & \\
\hline 11 & Clear statement of findings & & & \\
\hline 12 & Justification of data interpretation & & & \\
\hline 13 & Clear demarcation between data and researcher's views & & & \\
\hline 14 & General transferability of the research & & & \\
\hline 15 & Was research useful and relevant? & & & \\
\hline 16 & Will the results help? & & & \\
\hline
\end{tabular}

Note. Total marks $=32$ (Articles must have received $80 \%$ for inclusion into the study). 
Table 2

List of Articles Included in the Metasynthesis

Hewege, C. R. \& Perera, L. C. R. (2013). Pedagogical significance of wikis: towards gaining

effective learning outcomes. Journal of International Education in Business, 6(1), 51-70.

Chen, B. \& Bryer, T. (2012). Investigating instructional strategies for using social

media in formal and informal learning. The International Review of Research in

Open and Distributed Learning, 13(1), 87-104.

Kenney, J., Kumar, S., \& Hart, M. (2013). More than a social network: Facebook as a catalyst

for an online educational community of practice. International Journal of Social Media and

Interactive Learning Environments, 1(4), 355-369.

Minocha, S. \& Roberts, D. (2008). Social, usability, and pedagogical factors influencing

students' learning experiences with wikis and blogs. Pragmatics \& Cognition, 16(2), 272-306.

Schroeder, A., Minocha, S., \& Schneider, C. (2010). The strengths, weaknesses, opportunities

and threats of using social software in higher and further education teaching and learning.

Journal of Computer Assisted Learning, 26(3), 159-174.

Veletsianos, G. \& Navarrete, C. (2012). Online social networks as formal learning

environments: Learner experiences and activities. The International Review of Research

in Open and Distributed Learning, 13(1), 144-166.

\section{Trustworthiness in the Qualitative Metasynthesis}

In order to ensure trustworthiness of the metasynthesis, it was described in detail as it unfolded to leave an audit trail. The structure of a metasynthesis as detailed by Paterson, Thorne, Canam, \& Jillings (2001) was followed. Trustworthiness was further ensured by documenting the process of screening the selected research articles for inclusion or exclusion. Furthermore, trustworthiness was achieved by reviewing each article at least three times. An additional researcher reviewed our analysis of each article and gave input on the codes, quotations, and themes identified in the meta-study. We consulted and shared reviews with peers and with a colleague specializing in technology-enhanced learning regarding the data analysis processes and the identification of codes and themes. 
During the meta-data analysis, we read through each article and noted the possible themes as we progressed, using a highlighter on hard copies of the articles to get an idea of the phenomenon of e-learning and the use of social media in order to enhance the learning process. We read through each article at least three times and loaded the articles on the AtlasTI computer programme to assist with data organization and data analysis. The codes that were identified during the reading of the articles and codes in the OCL framework were loaded on AtlasTI. The codes were continuously updated and added to the data analysis to include inductive and deductive data and codes to ensure a complete picture of social media in e-learning.

\section{Data Analysis}

As indicated earlier, a metasynthesis comprises distinctive phases; namely, the meta-method analysis, the meta-data analysis and the meta-theory analysis, which is the systematic analysis of the qualitative research body of knowledge on social media and e-learning. The meta-method analysis is summarized in Table 3.

\section{The Meta-Method Analysis}

The purpose of the meta-method analysis was to determine how the interpretation and implementation of qualitative research methods have impacted on the research findings and the emergent theory on the use of social media in e-learning in higher education. Table 3 displays the epistemological soundness of the research methods, demographic data, and general research aspects of the studies such as sample, social media, country, and research characteristics.

Each of the articles was analyzed in order to determine how the authors methodologically presented aspects such as aim and purpose of the studies, the research questions, trends in social media use, research design, data collection and data analysis, and the trustworthiness of the studies. Table 3 indicates that the research methods were mainly basic qualitative research using interviews. Four of the studies used traditional data collection methods, such as interviews and focus groups, to research e-learning and social media in the digital era. The structure did not make use of digital qualitative research methods such as online discussion, digital audio data collection, or visual digital media for their data collection. The sample criterion indicated that staff and students from higher educations were selected in the study. The social networks criterion gives information about the specific social media that were used in the original research. The most proliferate social media were blogs, wikis and Facebook. The country criterion was a simple reflection of the places where the research was conducted; and this study indicated that qualitative research on social media in e-learning was dominated by the USA and the UK. 
Table 3

Summary of Methodological Aspects in the Different Data Sources

\begin{tabular}{|c|c|c|c|c|c|c|}
\hline Studies & $\begin{array}{l}\text { Hewege \& } \\
\text { Perera } \\
(2013)\end{array}$ & $\begin{array}{l}\text { Chen \& Bryer } \\
\text { (2012) }\end{array}$ & $\begin{array}{l}\text { Kenney et al. } \\
\text { (2013) }\end{array}$ & $\begin{array}{l}\text { Minocha \& } \\
\text { Roberts } \\
\text { (2008) }\end{array}$ & $\begin{array}{l}\text { Schroeder } \\
\text { Minocha \& } \\
\text { Schneider } \\
\text { (2010) }\end{array}$ & $\begin{array}{l}\text { Veletsianos \& } \\
\text { Navarrete } \\
\text { (2012) }\end{array}$ \\
\hline $\begin{array}{l}\text { Clear } \\
\text { research } \\
\text { questions }\end{array}$ & $\begin{array}{l}\text { Yes: } \\
\text { One question }\end{array}$ & $\begin{array}{l}\text { Yes: } \\
\text { Three questions }\end{array}$ & $\begin{array}{l}\text { Yes: } \\
\text { One question }\end{array}$ & $\begin{array}{l}\text { Yes: } \\
\text { Three } \\
\text { questions }\end{array}$ & Not stated & $\begin{array}{l}\text { Yes: } \\
\text { Two questions }\end{array}$ \\
\hline $\begin{array}{l}\text { Clearly } \\
\text { stated } \\
\text { study aims }\end{array}$ & $\begin{array}{l}\text { Yes: } \\
\text { To explore the } \\
\text { effectiveness } \\
\text { and } \\
\text { pedagogical } \\
\text { implications of } \\
\text { integrating } \\
\text { wikis into the } \\
\text { curriculum }\end{array}$ & $\begin{array}{l}\text { Yes: } \\
\text { To investigate } \\
\text { pedagogical asp } \\
\text { of } \\
\text { using social } \\
\text { media to } \\
\text { connect } \\
\text { formal and } \\
\text { informal } \\
\text { learning }\end{array}$ & $\begin{array}{l}\text { Yes: } \\
\text { To } \\
\text { demonstrate } \\
\text { that Facebook } \\
\text { be used } \\
\text { as a means } \\
\text { of building } \\
\text { an } \\
\text { online CoP }\end{array}$ & $\begin{array}{l}\text { Yes: } \\
\text { To } \\
\text { empirically } \\
\text { investigate } \\
\text { the role of } \\
\text { wikis and } \\
\text { blogs in } \\
\text { teaching and } \\
\text { learning }\end{array}$ & $\begin{array}{l}\text { Yes: } \\
\text { To explore } \\
\text { the } \\
\text { benefits of } \\
\text { introducing } \\
\text { social } \\
\text { software } \\
\text { into a } \\
\text { course }\end{array}$ & $\begin{array}{l}\text { Yes: } \\
\text { To identify, } \\
\text { describe, } \\
\text { and understand } \\
\text { learners' } \\
\text { experiences } \\
\text { in online learnins } \\
\text { through } \\
\text { social media }\end{array}$ \\
\hline $\begin{array}{l}\text { Research } \\
\text { design }\end{array}$ & $\begin{array}{l}\text { Exploratory } \\
\text { qualitative }\end{array}$ & $\begin{array}{l}\text { Exploratory } \\
\text { qualitative }\end{array}$ & $\begin{array}{l}\text { Exploratory } \\
\text { qualitative }\end{array}$ & Case study & $\begin{array}{l}\text { Exploratory } \\
\text { qualitative }\end{array}$ & $\begin{array}{l}\text { Exploratory } \\
\text { qualitative }\end{array}$ \\
\hline $\begin{array}{l}\text { Data } \\
\text { collection }\end{array}$ & $\begin{array}{l}\text { Content of } \\
\text { student- } \\
\text { generated } \\
\text { wikis and } \\
\text { assignments }\end{array}$ & Interviews & $\begin{array}{l}\text { Focus } \\
\text { Groups }\end{array}$ & $\begin{array}{l}\text { Content of } \\
\text { student- } \\
\text { generated } \\
\text { wikis and } \\
\text { e-mails }\end{array}$ & Interviews & Interviews \\
\hline $\begin{array}{l}\text { Data } \\
\text { analysis }\end{array}$ & $\begin{array}{l}\text { NVivo } \\
\text { data analysis }\end{array}$ & $\begin{array}{l}\text { Thematic } \\
\text { analysis and } \\
\text { comparative } \\
\text { coding }\end{array}$ & $\begin{array}{l}\text { Content } \\
\text { analysis }\end{array}$ & $\begin{array}{l}\text { Inductive } \\
\text { analysis }\end{array}$ & $\begin{array}{l}\text { Thematic } \\
\text { SWOT } \\
\text { analysis }\end{array}$ & $\begin{array}{l}\text { Constant } \\
\text { comparative } \\
\text { method }\end{array}$ \\
\hline $\begin{array}{l}\text { Data } \\
\text { description } \\
\text { and rigour }\end{array}$ & $\begin{array}{l}\text { A line-by-line } \\
\text { analysis or } \\
\text { microanalysis } \\
\text { was performed } \\
\text { on the content }\end{array}$ & $\begin{array}{l}\text { Full analysis } \\
\text { by one coder } \\
\text { followed by } \\
\text { re-coding by the } \\
\text { second coder }\end{array}$ & $\begin{array}{l}\text { Independent } \\
\text { coding was } \\
\text { followed by } \\
\text { the } \\
\text { comparison } \\
\text { of codes }\end{array}$ & $\begin{array}{l}\text { Dual-coding } \\
\text { by the two } \\
\text { independent } \\
\text { coders }\end{array}$ & $\begin{array}{l}\text { Independent } \\
\text { analysis was } \\
\text { followed } \\
\text { by joint } \\
\text { analysis }\end{array}$ & $\begin{array}{l}\text { Independent } \\
\text { analysis was } \\
\text { followed } \\
\text { by joint analysis }\end{array}$ \\
\hline Sample & $\begin{array}{l}\text { 8o students, } 30 \\
\text { assignments, } \\
6 \text { academics } \\
\text { Australia }\end{array}$ & $\begin{array}{l}57 \text { public } \\
\text { administration } \\
\text { faculty } \\
\text { Members USA }\end{array}$ & $\begin{array}{l}16 \mathrm{PhD} \\
\text { students } \\
\text { USA }\end{array}$ & $\begin{array}{l}\text { 70 students } \\
\text { (wikis), } \\
15 \text { students } \\
\text { (blogs) the U }\end{array}$ & $\begin{array}{l}20 \text { social } \\
\text { software } \\
\text { initiatives } \\
\text { from UK }\end{array}$ & $\begin{array}{l}\text { 10 Masters } \\
\text { and doctoral } \\
\text { students } \\
\text { USA }\end{array}$ \\
\hline $\begin{array}{l}\text { Social } \\
\text { media in } \\
\text { e-learning }\end{array}$ & $\begin{array}{l}\text { The use of } \\
\text { wikis }\end{array}$ & $\begin{array}{l}\text { Blogs, wikis, } \\
\text { Facebook, } \\
\text { virtual worlds }\end{array}$ & $\begin{array}{l}\text { Application of } \\
\text { Facebook }\end{array}$ & $\begin{array}{l}\text { Blogs and } \\
\text { wikis }\end{array}$ & Social media & Elgg \\
\hline
\end{tabular}




\section{The Meta-Data Analysis}

Seven distinct themes have emerged from the data. The concept of the theoretical framework for the study such as idea generation, idea organization, and knowledge building was clearly deduced from the data. Themes such as social learning, deep learning, student support, and safe environment emerged from the data as displayed in the meta-data analysis. Reference was made to the various data sources by numbering the articles from two to seven-for example, (5:116) - where five indicated the data source number and 116 the place or reference in the data source. The main purpose of the meta-data analysis was to extend knowledge about the use of social media in e-learning in higher education from the theoretical perspective of online collaborative learning (OCL) (Harasim, 2012).

\section{Themes from the Online Collaborative Learning Theory by Harasim (2012)}

The online collaborative learning (OCL) theory, according to Figure 1, provides a theoretical framework to help design and inform activities in e-learning. The OCL theory advances from idea generation and idea organization to the intellectual convergence stage. E-learning activities are linked with conceptual processes to encourage deep learning in technology-enhanced learning environments. The three stages of the OCL were evident in the metasynthesis and described as theme one to three in this study.

\section{Theme One: Idea Generation}

This theme was about blogging and wikis and how students use it in e-learning. Blogging, as part of education, is a type of online journal that enables the teacher and the students to post comments on course content. Blogs can be used as learning and communication tools. In this study it was evident that students did not use them as learning tools, but rather as private communication tools. It is evident that the students must be made aware of the main aim of the blogs, such as an administrative blog for lecturers to post learning material. The second type of blog in education is the whole-class-blog for the purpose of comments on the lecturer's post on course content. Lastly, there could be individual student blogs for reflection on the learning process.

When you write a study blog it's very personal and you mainly write it for yourself, and any coursemates who might look in. The blog was for me and not for anybody else. I could also demonstrate to my tutor that I was alive and working. These students' blogs were personal and they did not expect or seek comments and rarely read or responded to any comments that they received. $(5: 48)$

Wikis are tools that are shared spaces where teachers and students are able to post and build content in order to create a collaborative piece of information. In education, the purpose of wikis and blogs is very much the same, but wikis are focused on co-construction of knowledge by a group of students to promote constructivism in education. The participants in this meta-study reflect as follows on wikis in education:

One student noted: Initially when the task was presented to us, I was hesitant to contribute, as I did not fully understand what was required" "Other students waited to see the wiki contributions 
from multiple students and hence claimed: when few students initially contributed, [it was] very difficult to engage. (3:4)

\section{Theme Two: Idea Organization}

This theme includes aspects on how students make sense of the knowledge and how problem-solving is employed to assist in making sense in learning. Meaning is one of the responsibilities of education to draw attention to noticeable aspects and ways in which meaning is constructed in the text digitally as well as how we fulfil our intentions in the world. The concept of community of practice (CoP) or community of inquiry (Col) in social media and education where people work together through interactions to create discourse by means of constructivism consists of mainly three components: teaching presence, cognitive presence, and social presence. This is described as follows:

In the $\mathrm{CoP}$ in this research study, students continually negotiated meaning, worked towards their individual and collective goals, shared their application of learning in their practice, and supported each other through the rigors of doctoral study. (4:28)

Problem-solving is an important part of many disciplines; and the development of problem-solving skills requires a sound knowledge base with various concepts and the ability to interconnect these concepts.

Within a CoP the community is built and the practice is supported through the sharing of knowledge relevant to the shared domain of interest, but also through the sharing of self through personal and professional interactions. Working towards a common goal or finding collective solutions to problems in this CoP included such activities as explaining wrong answers (knowledge sharing), providing motivation (support), and explaining where to find resources (problemsolving). (4:21)

\section{Theme Three: Knowledge Building}

In this theme, students reach an agreement to disagree or to reach consensus. Knowledge construction and collaboration in terms of e-learning can be described as the process that suggests that students are much more actively involved in the joint enterprise with the teacher and peers in creating knowledge. The participants in the various studies describe knowledge building in terms of constructivism and the use of the wiki in education as follows:

The wiki activities involved a group of students contributing requirements to the group-wiki, discussing the requirements, identifying conflicts and ambiguities within the requirements, and resolving the conflicts through discussions from the perspectives of different stakeholders, to produce an unambiguous requirements specification. The wiki activities were designed to be selfmanaged by the students and required minimal or no intervention by the tutor and thereby avoided any significant increase in the tutors' workload. (5:5)

Students expressed in interviews and reflective accounts that wiki-based collaboration had facilitated their learning and that they became aware of the various issues and challenges of team-working in virtual teams in real-world software engineering projects. (5:17) 


\section{Emergent Themes from the Meta-Data Analysis}

Four new themes (themes four to seven) emerged from the qualitative data on social media and e-learning; namely, social learning, deep learning, student support, and learning environment, as displayed in Figure 4. The OCL framework themes together with the four emerging themes below completed the framework for using social media in e-learning in this metasynthesis.

\section{Theme Four: Social Learning}

The theme consisted of social media and constructivism. Social media are simply digital technologies that allow us to create and share knowledge and material with others via the internet. Social media is all about participation, collaboration, interactivity, community-building, sharing, networking creativity, distribution, and flexibility. Constructivism is rooted in the works of Piaget (1896-1980) and Vygotsky (1896-1934) in which the learning process is informed by cultural influences (Harasim, 2012) and is described as follows:

The notion of social learning can be traced back to the theory of social constructivism in the 1960s. The basic principle is that students learn most effectively by engaging in carefully selected collaborative problem-solving activities, under the close supervision of instructors. Collaboration is the most important characteristic of social learning. While instructors help to facilitate group interactions, students have the autonomy to self-select what they need to learn to gain a better understanding of the problem. (2:6)

Learners supported one another in their learning and noted that they perceived their learning experience was enhanced by their interactions. Additionally, students did not appear to mix social and educational participation and seemed to need support in managing the expanded amount of information available to them. In order to manage their time and participation, learners devised strategies and "workarounds" to complete assigned activities and course commitments. (7:6)

\section{Theme Five: Deep Learning}

Theme five was all about building trust, meaning in learning, and cognitive deep learning. Trust is about effective teamwork and team members; and everyone is contributing equally and behaving appropriately and differences of opinion in the team can be sorted out in a supportive environment. Deep learning is described in terms of trust, interaction with other students, and reflection, as follows:

It is the willingness to trust, interact, and share with others that develops a sense of belonging to the community. In this instance, one of the main functions of the $\mathrm{CoP}$ is the interactions amongst members who are geographically disbursed [sic].(4:37)

Reflection is the process of stepping back from an experience to ponder, carefully and persistently, it's meaning to the self through the development of inferences; learning is the creation of meaning from the past or current events that serve as a guide for future behaviour. One of the goals of reflective learning is to encourage professionals to recognise the routine, implicit skills in their practice, which tend to be delivered without conscious deliberation or a deeper questioning of the 
wider situation or context within which the practitioner is operating. (5:21)

\section{Theme Six: Student Support}

This theme was about a community of practice, which is a support structure where people come together to share knowledge and create a discourse through interaction as educators become more student-centred in their approach to teaching and learning. Those who are using social media in their teaching move from covering the content to helping students to master learning. This study indicates student support via social media as follows:

This research demonstrates that it is possible to use Facebook as a student-developed CoP to facilitate collaboration and community-building among students in support of their learning. Group members appeared to be more comfortable asking questions and seeking clarification within the informal Facebook community than in more formal or official virtual spaces in their online programme where faculty members were present. (4:47)

It is the interweaving of the community and the practice within the domain which is the foundational aspect of the CoP. The domain for this example includes being both a practitioner of educational technology and a student in the online doctoral programme in educational technology. $(4: 5)$

\section{Theme Seven: Learning Environment}

This theme was about the safety and security issue when using social media in academia and related problems around it which are worth mentioning. Most universities do not have control over terms and conditions of social media. When agreeing to the terms and conditions of social media, lecturers and students take the responsibility on themselves to comply and act within the legal boundaries. You should monitor the sites and visibility of your work. The participants in this study seem to be mindful of safety issues when using social media in education and reflect as follows:

Only in five of our twenty cases, the institutions reported of explicit attempts to safeguard the issues of a social software initiative. The safeguarding focused on reminding the students of the existing institution's computing code of conduct asking the students to formulate policies, or simply informing the students about the risks. Interestingly, we did not encounter any initiative which created specific safeguards to protect students from outside harm, although the threats are wellknown. We found that social software initiatives are largely initiated and carried out by individual educators with little guidance and support from their institutions. However, to mitigate these risks, institution-level support and interventions will help to manage the threats and to initiate a discourse which engages students and educators to formulate sound and practical solutions and guidelines. (6:3) 


\section{Meta-Theory Analysis}

The meta-theory aspect of this research involved the analysis of a detailed study of research work on social media and the study of research into relevant e-learning theories. The major paradigms underlying the theoretical frameworks that were investigated were included in social learning theory, social interactivity theory, constructionism and social constructivism, and online collaborative learning theory (Harasim, 2012). Collaboration and social constructivism were the main theoretical frameworks guiding the use of social media in e-learning in higher education that point towards a more integrative (collaborative) and coconstructivism peer supportive approach to learning in the digital age.

\section{Discussion and Insights from the Data}

Each of the three analytic phases namely, the meta-method, the meta-theory and the meta-data analysis provided a unique angle or vision from which social media and e-learning were deconstructed and interpreted. In the following part of the paper, we consider the metasynthesis as it shaped the larger context of the project on social media and e-learning in ODL. It is not possible to predict the extent to which new knowledge or new theory can be synthesized, until the products of the meta-data analysis, meta-method and meta-theory are individually and collectively interpreted.

The larger intent of the meta-synthesis is not to raise questions about highlighted issues, but to build a framework or to provide good practice guidelines for practice. The appeal for metasynthesis lies in our hunger for more truth, more accurate and real explanations and practice guidelines to make sense of our everyday practices and, in this case, the use of social media in e-learning.

\section{Insights from the Meta-Method Analysis}

The meta-method analysis offered a strategy to reflect on the role of research methodology and how it shaped the findings of individual studies. From the meta-method analysis, we begin to identify the nuances of the various qualitative approaches in e-learning. To an extent, the methods reflected the academic discipline choices; and in this metasynthesis, the qualitative research in social media and online learning pointed to an exploratory level of research.

The included studies used explorative qualitative research methods; and one case study indicates that the academic interrogation in e-learning is not yet at theory development level and that most research is just scratching the surface. The data analysis methods in social media and e-learning qualitative research were also at line-by-line analysis level and not at synthesis level yet. The studies used mostly wikis, Facebook, and blogs as social media to enhance e-learning in this study. 


\section{Insights from the Meta-Theory Analysis}

The meta-theory created the context in which the implications of a range of theoretical approaches impacted on the body of knowledge. Each primary qualitative article was studied individually and comprehensively for demographic and theoretical context to understand the different ways that researchers obtained various findings through the last decade on social media in e-learning. The research in e-learning and social media use is currently still at a social learning theoretical level without the use of educational pedagogies and conceptual frameworks. An alarming fact was that most of the studies in this synthesis referred to social constructivism, but did not interrogate the use of educational theories in e-learning further than just a sentence or two in the literature review. In the context of these theoretically poor underpinnings in the qualitative research, we did not interpret any particular conflict between the studies, but we did arrive at a comprehensive theory for the use of social media in e-learning which could assist the users of e-learning with a framework for decision-making as to the nature of the social media and its fitness for purpose in the various modules or courses in e-learning.

\section{Synthesizing Insights}

Seven distinct themes have emerged from the data and include idea generation, idea organization and knowledge building as described in the online collaborative learning (OCL) model as displayed in Figure 1. Emerging from this metasynthesis are the themes of social learning, deep learning, student support, and safe environment depicted in Figure 3. The metasynthesis indicates that for e-learning with social media to be successful, all teaching and learning efforts must be anchored in student support since student support is the foundation of any learning and especially e-learning.

The metasynthesis for the use of social media in e-learning indicates that for effective and deep learning to take place in higher education, students must be guided in blogging and using wikis for the co-construction of knowledge. Students must be able to generate ideas because these ideas are required for engaging in group dissuasion, brainstorming, and articulating views and discussions related to knowledge issues in their respective disciplines. See figure 4.

Secondly, the ideas must be organized and refined by the students through the processes of problem-solving and making sense of academic content. Students start organizing, analyzing and filtering ideas through agreement or disagreement with others in the group. Input from the facilitator might be needed as a form of moderation and analysis to cluster ideas into meaningful units and knowledge building. Analytical skills are needed in the process.

Thirdly, knowledge creation, displayed in Figure 4, must be facilitated through social learning strategies such as real life examples, collaboration, and constructivist pedagogy. Students must be supported by interaction, guidance, and clear learning outcomes. Intellectual processes must take place, such as discussions and analysis of information through a process of convergence and synthesis of concepts to create knowledge. Intellectual convergence is also characterized by agreements and disagreements with the final product being a piece of knowledge created by a group of people or students or colleagues. In this 
process the group members move towards consensus in the knowledge creation process.

For intellectual convergence and consensus on academic knowledge creation, the students or group members need a safe and secure environment to work in. Social media tools are important in the learning process. Central to collaborative learning and knowledge building is the need for a shared space for discourse and interaction. Therefore, higher education institutions that are moving towards adopting social media to facilitate knowledge creation must ensure that the participants can do it in a safe and supportive environment. See Figure 4.

Lastly and perhaps most importantly, is the student's support factor, which emerged from the data coupled with a community of practice or communities of inquiry in e-learning. A well-known feature of ODL is the distance between the student and the lecturer, the institution, and the other students. With e-learning and the use of social media, the loneliness could be changed to communities of practice $(\mathrm{CoP})$ or communities of inquiries (CoI). Social commitment, interactions, and friendships form the glue for all communities of practice and motivate active and regular member participation. Social and academic discourse in e-learning could be a mechanism for participation and knowledge building which is a part of constructivism and important for deep learning. For the framework for using social media in e-learning as displayed in Figure 4 to be effective, social engagement in which members of the academic module or course must demonstrate commitment and active participation in a safe and trusting environment.

Among other things, Wenger, McDermott, and Snyder (as cited in Hartnell-Young and Morriss, 2007) suggested that any learning community must interact with other communities of practice in a purposeful way. The traditional isolation of the teacher must change to a more collegial approach to learning and communication as knowledge sharing is now possible. Interaction with the online community of practice provides teachers and educators with a global perspective as people from many countries communicate without ever meeting one another in person. 


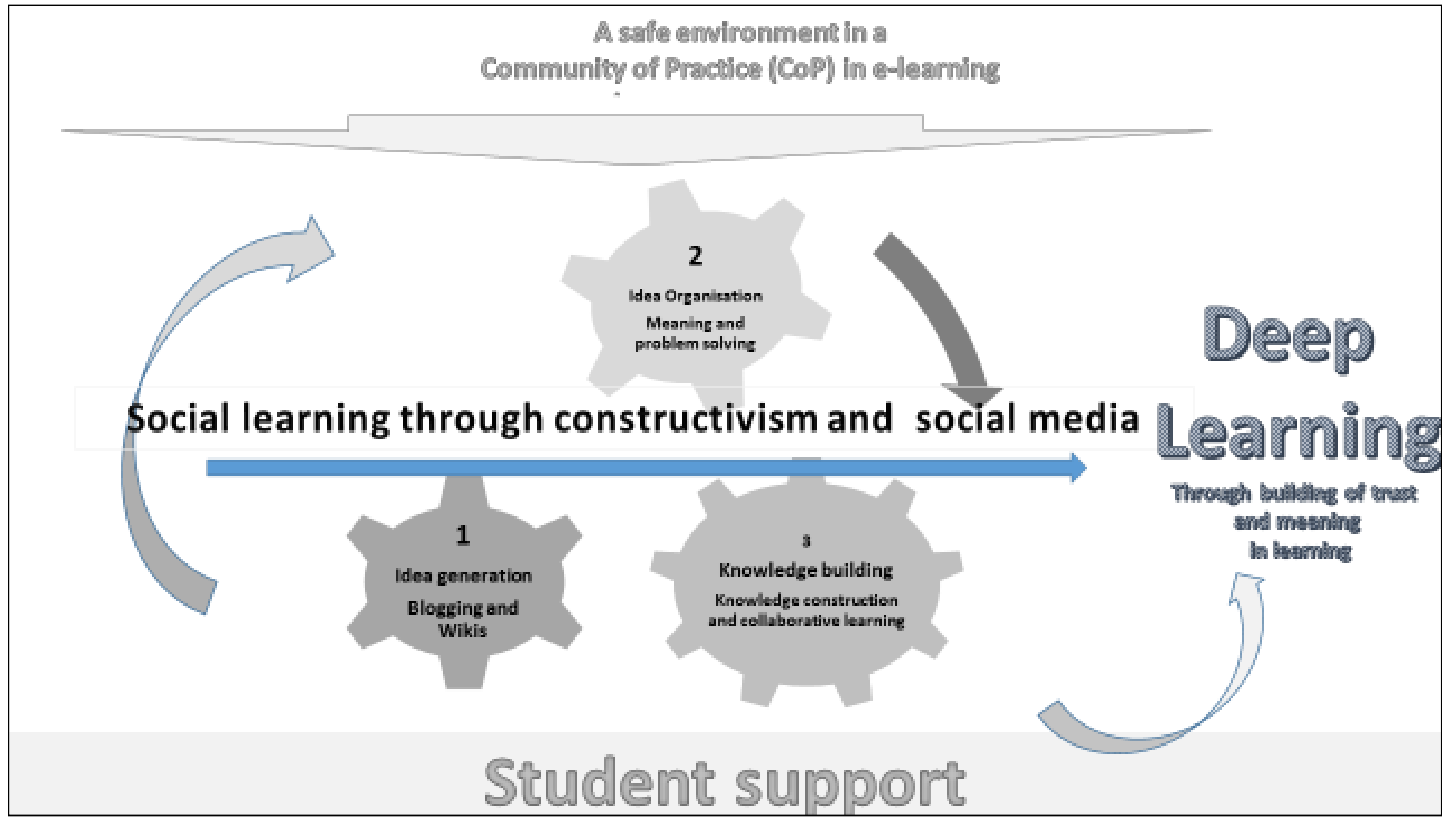

Figure 4. The framework for using social media in e-learning (adapted from the OCL theory by Harasim, 2012). 


\section{Implications for e-Learning}

The metasynthesis indicates that most qualitative researchers in e-learning and the use of social media are still at the entry level of qualitative research and interviews instead of electronic resources are used to collect data. It is evident that e-learning in higher education is pointing towards a more integrative (collaborative) and constructivism and supportive approach for learning in the digital age as illustrated in Figure 1, the OCL theory Harasim 2012) and Figure 4. The conclusion of this metasynthesis is deemed to be valuable and applicable to use for planning and managing e-learning, using social media in higher education, as illustrated in Figure 4.

If educators in higher education and ODL really want deep learning for their students in e-learning environments, it is important to plan interactions and strategies for using social media in e-learning by using the framework in Figure 4. The framework is based on the work of Harasim (2012) concerning online collaborative learning, which is aimed to ensure that students are supported, safe, and connected in their learning journey.

Inasmuch as social media has significantly reduced the gap between learners, their peers, and their teachers, we should not forget that there are still important things that students miss in e-learning. The use of wikis and blogs in e-learning could facilitate social learning, peer review and co-creation of knowledge. Idea organization could be facilitated through the community of practice by using discussion forums, blogs or wikis for students to refine ideas by means of the OCL theory as described by Harasim (2012) and the emerging themes from this metasynthesis.

There may be positive signs that these social networking tools will enable learning environments that are more personal, participatory and collaborative learning spaces. For deep learning to occur, we have to consider careful planning in e-learning (McLoughlin \& Lee, 2007). Intellectual convergence or knowledge construction happens when students form collaborative online groups to facilitate communities of practice in which they can refine ideas.

As shown above, concepts that emerged during meta-analysis and illustrated in Figure 1 and Figure 4, social media facilitate communication among the learners and between the learners and the teacher by forming social links among the participants. Once social networks such as CoPs are formed, knowledge is shared which leads to learning and the creation of new knowledge through collaborative activities. If students could use social media within the CoPs and feel safe and supported to build knowledge, the social learning could facilitate deep learning.

\section{Conclusion}

The findings showed that the use of social media still lacks important empirical data. The proposed framework could be useful to instructional designers who are interested in using modern learning theories and who want to adopt social media in e-learning in higher education as a deep learning 
strategy.

In conclusion, through this metasynthesis, a conceptual framework was developed for using social media such as blogs and wikis for idea generation, problem-solving through discussions, Skype or Google Hangout, Facebook, and even mobile apps, such as WhatsApp, to organize and co-create knowledge. This can only happen in a safe and supportive environment in e-learning where deep learning is facilitated through building trust in one another and in the learning process within a $\mathrm{CoP}$. In a CoP, online students can refer, talk, or discuss and validate academic issues and co-create knowledge constructively. Students in e-learning can be developed into individuals who are technologically skilled for the digital age and who find meaning in learning through e-learning with technologies and social media.

\section{References}

Bates, A. W. (2015). Teaching in a digital age. Vancouver, B.C.: Tony Bates Associates Ltd.

Retrieved from http://opentextbc.ca/teachinginadigitalage/

Carpenter, J. P. \& Krutka, D. G.( 2015). Social media in teacher education. In M.L.Niess, . \& H. Gillow-Wiles (Eds.), Handbook of research on teacher education in the digital age (pp. 28-54) Hersey, PA: IGI Global.

Chen, B., \& Bryer, T. (2012). Investigating instructional strategies for using social media in formal and informal learning. The International Review of Research in Open and Distributed Learning, 13(1), 87-104.

Hadjerrouit, S. (2010). A conceptual framework for using and evaluating web-based learning resources in school education. Journal of Information Technology Education, 9, 53-79.

Harasim, L. (2012). Learning theory and online technology. New York, NY: Routledge.

Hartnell-Young, E. \& Morriss, M. (2007). Digital portfolios-Powerful tools for promoting professional growth and reflection ( $2^{\text {nd }}$ ed.). Thousand Oaks: Corwin Press.

Hewege, C. R. \& Perera, L. C. R. (2013). Pedagogical significance of wikis: towards gaining effective learning outcomes. Journal of International Education in Business, 6(1), 51-70. 
Kenney, J., Kumar, S., \& Hart, M. (2013). More than a social network: Facebook as a catalyst for an online educational community of practice. International Journal of Social Media and Interactive Learning Environments, 1(4), 355-369.

McLoughlin, C., \& Lee, M. J. (2007). Social software and participatory learning: Pedagogical choices with technology affordances in the Web 2.0 era. In: ICT: Providing Choices for Learners and Learning. Proceedings ascilite Singapore 2007. 664-675.

Mehlenbacher, B., Bennett, L., Bird, T., Ivey, M., Lucas, J., Morton, J., \& Whitman, L. (2005). Usable online learning: A conceptual model for evaluation and design. In Proceedings of HCI International 2005: 11th International Conference on Human-Computer Interaction, Volume 4-Theories, Models, and Processes in HCI. Las Vegas, NV: Mira Digital P, pp. 110.

Minocha, S., \& Roberts, D. (2008). Social, usability, and pedagogical factors influencing students' learning experiences with wikis and blogs. Pragmatics \& Cognition, 16(2), 272-306.

Park, Y. (2011). A pedagogical framework for mobile learning: Categorizing educational applications of mobile technologies into four types. The International Review of Research in Open and Distributed Learning, 12(2), 78-102.

Paterson, B. L., Thorne, S. E., Canam, C., \& Jillings, C. (2001). Meta-study of qualitative health research: A practical guide to meta-analysis and meta-synthesis. Thousand Oaks: Sage.

Petersen, D. (2007). Usability theory, practice and evaluation for learning objects. In K. Harman \& A. Koohang (Eds.), Learning objects: Applications, implications, \& future directions (pp. 337-370). Santa Rosa, CA: Informing Science Press.

Sandelowski, M., Trimble, F. M., Woodard, E. K., \& Barroso, J. (2006). From synthesis to script: Transforming qualitative research findings for use in practice. Qualitative Health Research, 16(10), 1350-1370.

Schroeder, A., Minocha, S., \& Schneider, C. (2010). The strengths, weaknesses, opportunities and threats of using social software in higher and further education teaching and learning. Journal of Computer Assisted Learning, 26(3), 159-174.

Thorne, S., Paterson, B., Acorn, S., Canam, C., Joachim, G., \& Jillings, C. (2002). Chronic illness experience: insights from a metastudy. Qualitative Health Research, 12(4), 437-452.

Veletsianos, G. \& Navarrete, C. (2012). Online social networks as formal learning environments: Learner experiences and activities. The International Review of Research in Open and Distributed Learning, 13(1), 144-166. 
The Use of Social Media in E-Learning: A Metasynthesis

Mnkandla and Minnaar

Athabasca
University

(c) 